\title{
TRANSACTION COSTS IN INTERNATIONAL ARMAMENTS COOPERATION
}

\author{
Vladan Holcner, Marek Sedlačik, Jaroslav Michálek, Jakub Odehnal*
}

\begin{abstract}
:
The aim of this paper is to examine and provide new evidence on changes in the costs and other determinants of economic rationality of international sharing of armaments projects. Based on current transaction costs theory, it defines individual and collective transaction costs of a weapon systems club. Using results of questionnaire survey, gathering expectations of international expert armaments community, there are analysed relations anticipated among those determinants, which are decisive for the amount of project costs. Results of these analyses indicate general anticipation of decreased total project costs in case of international sharing of armaments projects, along with increased project transparency, which can be viewed as one of the generators of decreased total costs. Transaction costs have indicated an unchanged level or a moderate decrease. Their individual component is to decrease. On the other hand, collective transaction costs are to grow, however, up to the extent of the decrease of individual transaction costs.
\end{abstract}

Keywords: defense, armaments, international cooperation, transaction costs, factor analysis, non-parametric statistics.

JEL Classification: F5, C4, H7, H8

\section{Introduction}

Recent developments in military spending of most Western and Central European countries have strengthened the antagonism between the amount of public resources allocated to defense and the generally unchanging defense ambitions and commitments. Substantial cuts in military spending by Western and Central European countries resulted in an annual overall decrease of $1.9 \%$ in the region in 2011 . These cuts are in sharp contrast with the steadily growing worldwide military spending in many other regions, e.g. in Eastern Europe by $20.2 \%$, in Africa by $8.6 \%$ or Middle East by $4.6 \%$, worldwide by $0.3 \%$ (SIPRI, 2011). In addition, due to the lasting debt crisis, prevailing expectations show that defense sectors in Western and Central European countries will continue to develop under conditions of austerity in the years to come.

These trends necessitate approaches enhancing the efficiency of resources allocated to defense, including the rationale of sharing defense burden as outlined e.g. in the EU Concept of "Pooling and Sharing" (European Commission, 2003) or in the NATO "Smart Defence" approach (NATO Summit Declaration on Defence Capabilities,

* Faculty of Economics and Management, University of Defence, Kounicova 65, CZ - 66210 Brno (vladan.holcner@unob.cz). 
2012). These approaches are based on the concept of sharing costs of delivering certain defense capabilities, i.e. international division of labour in defense.

There are several decisive determinants of international cooperation in this area. The very first and imperative one relates to the fact that defense represents purely public goods (Stiglitz, 1997), provided by national governments within a rather centralized system with limited competition on related partial markets. All the determinants influencing international armaments cooperation can be divided as economic and non-economic. Economic determinants include aspects of economy and efficiency, related mainly to comparative advantages, economies of scale and transaction costs. Non-economic determinants can be further classified as either technical or political/ security ones (Krč and Kamiňski, 1996). Technical determinants are derived from the need to acquire high-quality technology to minimize security threats. Political determinants represent a natural driving force in international armaments cooperation due to their vital importance to any nation. Armaments projects are often connected with concentrated public contracts that, again, are common subjects of political interests.

The aim of this paper is to assess and interpret relations and dependencies among variables characterizing expected values of international armaments cooperation determinants. In particular, the paper aims to:

1. Analyze correlation structure among variables characterizing transaction costs resulting from international armaments cooperation, compare and interpret individual levels of expectations.

2. Identify empirical determinants of transaction costs and compare them with theoretical factors described in literature.

3. Analyze trends of expected project total costs development in relation to overall transaction costs and other variables.

4. Evaluate consistency and structure of expectations of subject matter experts according to their classification in responders segments and verify validity of the survey results.

To fulfill the above listed aims, instruments of descriptive statistics, non-parametric statistics and multivariate statistical methods have been applied. All the calculations have been performed using the STATISTICA 8 software.

\section{Transaction Costs Theory}

Behaviour of stakeholders in armaments contracts cannot be satisfactorily explained by applying microeconomic assumptions of a rationally behaving consumer under conditions of perfect information. To explain the existence of transaction costs in armaments contracts, the theory of the so-called new institutional economics can be applied, based on the assumption of bounded rationality and opportunism. In the 
case of armaments contracts the contracting authorities (governments) do not have access to all relevant information. Gathering this information represents a substantial burden resulting in the growth of transaction costs. Similarly, the second assumption of opportunism consists in the notion of an individual whose objective is maximizing his personal benefits, i.e. his individual interests, and anticipates the subsistence of transaction costs. Nevertheless, a real economic environment becomes a form conscious of breaking conditions of competition or the presence of corrupt practices. Detailed classification of preconditions of the transaction costs theory (Gareth and Hill, 1988) identifies six main factors influencing implementation of a given transaction (bounded rationality, opportunism, uncertainty and complexity, small numbers, information impactedness and asset specificity).

Transaction costs, representing an integral part of costs of any armaments contract, have been analyzed already by Coase (1937) and Vahabi (2011), who have characterized the justification of the existence of firms as economic entities. The notion of a firm based on the assumption of overall cost minimization, which includes both production and transaction costs, has been further elaborated in the works of North and Wallis (1986), Williamson (1985), (1986), Matthews (1986) or Pavel (2004).

Using the example of the USA, the empirical study by North and Wallis (1986) analyses the development of transaction costs between the years 1870 and 1970 in relation to GDP. Matthews (1986) has classified ex ante and ex post transaction costs. A detailed analysis of transaction costs has been further elaborated by Williamson (1985). According to Furubotn and Richter (1998), transaction costs can be classified as market transaction costs, management transaction costs and political transaction costs.

Another approach classifies transaction costs as information costs, negotiation costs and contract monitoring costs (Hobbs, 1997). Information and negotiation costs are defined as ex ante transaction costs, monitoring costs belong to ex post transaction costs (Hobbs, 1997; similarly Matthews, 1986). Estimations of the amounts of such defined transaction costs have been published in several studies (Walsh and Davis, 1993; Audit Commission, 1995). In the case of ex ante transaction costs authors Walsh, Davis (1993) estimate their amount at the level of less than $2 \%$ of the transaction value and in case of ex post transaction costs these estimates state the level of nearly $4 \%$ of given transaction value (Audit Commission, 1995). Similar classification can be found in other publications as well (Dyer, 1997), where ex ante transaction costs include searching for potential commercial partners, costs of negotiations with partner(s), preparation of contract terms and conditions and monitoring costs. Ex post transaction costs then include the costs of enforcing a contract and applying sanctions.

Similar classification of transaction costs (Weber, 1997) considers transaction costs as one of the factors influencing defense cooperation among nations within a formal alliance or confederation. Weber examines two assumptions (bounded rationality and opportunism) and three characteristics of transactions in international defense 
cooperation (frequency of transactions, asset specificity and uncertainty). Transaction costs theory applied to decision-making problems of international defense cooperation stresses the key role of the factor of potential threats as a determinant of establishment of defense alliances or confederations.

\section{Analysis of Influence of Transaction Costs in International Armaments Cooperation Rationale}

As mentioned above, transaction costs represent an important component of armaments projects costs and therefore, belong to the determinants potentially promoting or hindering governments' will to internationally share their armaments projects. Only limited information on estimates or actual records of the amount of transaction costs in armaments contracts is available. What is their actual role in international armaments cooperation?

\subsection{Armaments Contracts Transaction Cost Analysis Framework}

The obvious lack of empirical data and case studies or their confidentiality represent a significant limit to an examination of links existing among individual determinants decisive for armaments international cooperation efficiency. Therefore the interviews or questionnaire surveys represent the only method to collect data on at least expectations of members of subject matter experts (Hartley, 1995). These experts consist of a heterogeneous population representing different interest groups (different nations, international organizations, industry, contracting authorities, and academia). To assure validity of the responses collected the survey has focused on the broad international NATO/EU expert community representing all interest groups. To gather the data required, this paper has followed the generally accepted approach (Kerlinger, 1986). This applies to the data evaluation and interpretation as well.

To examine the behaviour of selected variables of interest, especially individual project cost items (with special focus on transaction costs) a questionnaire survey has been carried out to collect the anticipations of altogether 126 Czech as well as international experts representing three main interest groups in $\mathrm{NATO} / \mathrm{EU}$ member countries - i.e. three categories of responders, representing:

- Defense industry;

- Contracting authorities (MoD);

- Academia.

The limited number of experts in the subject matter area along with their will to take an active part in the survey $(25 \%)$ has represented an important limitation. Nevertheless, the relatively low number of responders has been partially compensated by a substantial consistency of the replies gathered across individual categories of responders and across the domestic (Czech) and international (NATO/EU) community. 
The questionnaire consisted of 10 questions related to total armaments project costs, transaction costs and side-effects of international sharing of armaments projects. Tables 1, 2 and 3 below show a detailed description of these questions. Responses to these questions have enabled the identification of attitudes and expectations of individual responders regarding the variables in question. Answers to individual questions included in the questionnaire have been classified in an ordinal scale consisting of five levels of relationship (1 - strongly increasing, 2 - moderately increasing, 3 - neutral, 4 - moderately decreasing and 5 - strongly decreasing influence).

As indicated above, the survey included questions covering following areas:

a) Analysis of overall armaments project/contract costs (variable: Total Project Costs - TOC); for details see the Table 1 below;

Table 1

Description of Determinant(s) Related to Total Project Costs

\begin{tabular}{|l|l|}
\hline $\begin{array}{l}\text { DETERMINANT } \\
\text { (VARIABLE) }\end{array}$ & $\begin{array}{l}\text { MEASUREMENT (QUESTION CHARATERIZING EXPECTATIONS } \\
\text { OF EXPERT COMMUNITY) }\end{array}$ \\
\hline $\begin{array}{l}\text { Total project costs } \\
(T O C)\end{array}$ & $\begin{array}{l}\text { Do you think that overall costs of an armament project based on cooperation } \\
\text { of several governments would rather increase or decrease compared to the } \\
\text { variant when each government carries out this contract without cooperation } \\
\text { with other nations? }\end{array}$ \\
\hline
\end{tabular}

Source: Own.

b) Analysis of side effects of international cooperation (sharing) in armaments projects (variable: Project Transparency - PTR); for details see the Table 2 below;

Table 2

Description of Determinant(s) Related to Side Effects of International Armaments Cooperation

\begin{tabular}{|l|l|}
\hline $\begin{array}{l}\text { DETERMINANT } \\
\text { (VARIABLE) }\end{array}$ & $\begin{array}{l}\text { MEASUREMENT (QUESTION CHARATERIZING EXPECTATIONS } \\
\text { OF EXPERT COMMUNITY) }\end{array}$ \\
\hline $\begin{array}{l}\text { Project } \\
\text { transparency } \\
(P T R)\end{array}$ & $\begin{array}{l}\text { Do you expect that the collective approach of several nations to a joint } \\
\text { armament contract would rather increase or decrease the level of its } \\
\text { transparency compared to the variant when each government carries out } \\
\text { this contract without cooperation with other nations? }\end{array}$ \\
\hline
\end{tabular}

Source: Own.

c) Transaction costs analysis (variables: Costs of Searching for Suitable Partners for the Weapon System Club - PSC, Costs of Negotiating with Partners in the Weapon System Club $-P N C$, Costs of Enforcing Compliance by Weapon System Club Partner(s) $-P E C$, Costs of Collecting Information on Requirements $-I C C$, Costs of Negotiating with Contractor(s) $-C N C$, Contract Monitoring Costs $-C M C$, Contract Enforcement Costs $-C E C$, Collective Transaction Costs $-C T C$, Individual Transaction Costs - ITC, Overall Project Transaction Costs $-T R C$ ); for details see the Table 3 above. 
Table 3

Description of Determinant(s) Related to Side Effects of International Armaments Cooperation

\begin{tabular}{|c|c|}
\hline $\begin{array}{l}\text { DETERMINANT } \\
\text { (VARIABLE) }\end{array}$ & $\begin{array}{l}\text { MEASUREMENT (QUESTION CHARATERIZING EXPECTATIONS } \\
\text { OF EXPERT COMMUNITY) }\end{array}$ \\
\hline \multicolumn{2}{|r|}{ COLLECTIVE TRANSACTION COSTS (CTC) } \\
\hline \multicolumn{2}{|l|}{ Information Costs } \\
\hline $\begin{array}{l}\text { Costs of searching for } \\
\text { partner(s) }(P S C)\end{array}$ & $\begin{array}{l}\text { Do you expect that costs of searching out partner(s), who plan } \\
\text { to purchase identical weapon systems, would rather increase } \\
\text { or decrease overall armament project costs, which every government } \\
\text { would have to spend? }\end{array}$ \\
\hline \multicolumn{2}{|l|}{ Negotiation Costs } \\
\hline $\begin{array}{l}\text { Costs of negotiating } \\
\text { joint project terms } \\
\text { and conditions with } \\
\text { partner(s) }(P N C)\end{array}$ & $\begin{array}{l}\text { Do you expect that costs of negotiating joint project terms and } \\
\text { conditions with partner(s), who plan to purchase identical weapon } \\
\text { systems, would rather increase or decrease overall armament project } \\
\text { costs, which every government would have to spend? }\end{array}$ \\
\hline \multicolumn{2}{|l|}{ Monitoring Cost } \\
\hline $\begin{array}{l}\text { Costs of enforcing } \\
\text { compliance by partner(s) } \\
(P E C)\end{array}$ & $\begin{array}{l}\text { Do you consider enforcement costs of fulfilment of agreed terms } \\
\text { by partner(s), who plan to purchase identical weapon systems, } \\
\text { a significant risk of the project? }\end{array}$ \\
\hline \multicolumn{2}{|r|}{ INDIVIDUAL TRANSACTION COSTS (ITC) } \\
\hline \multicolumn{2}{|l|}{ Information Costs } \\
\hline $\begin{array}{l}\text { Costs of gathering } \\
\text { information about } \\
\text { requirements of own } \\
\text { armed forces and } \\
\text { adequate existing } \\
\text { technologies }(I C C)\end{array}$ & $\begin{array}{l}\text { Do you expect that costs of gathering information about requirements } \\
\text { of own armed forces and adequate existing technologies would } \\
\text { rather increase or decrease in case of cooperation of several } \\
\text { governments compared to the variant when each government carries } \\
\text { out this contract without cooperation with other nations? }\end{array}$ \\
\hline \multicolumn{2}{|l|}{ Negotiation Costs } \\
\hline $\begin{array}{l}\text { Costs of negotiation } \\
\text { terms and conditions } \\
\text { with contractor(s) (CNC) }\end{array}$ & $\begin{array}{l}\text { Do you think that costs of negotiation terms and conditions with contrac- } \\
\text { tor(s) would rather increase or decrease in case of cooperation of } \\
\text { several governments compared to the variant when each government } \\
\text { carries out this contract without cooperation with other nations? }\end{array}$ \\
\hline \multicolumn{2}{|l|}{ Monitoring Costs } \\
\hline $\begin{array}{l}\text { Costs of monitoring of } \\
\text { contract fulfilment by the } \\
\text { contractor(s) }(C M C)\end{array}$ & $\begin{array}{l}\text { Do you think that costs of monitoring of contract fulfilment by } \\
\text { the contractors(s) would rather increase or decrease in case } \\
\text { of cooperation of several governments compared to the variant when } \\
\text { each government carries out this contract without cooperation with } \\
\text { others nations? }\end{array}$ \\
\hline $\begin{array}{l}\text { Costs of possible } \\
\text { enforcement of contract } \\
\text { fulfilment by the } \\
\text { contractor(s) (CEC) }\end{array}$ & $\begin{array}{l}\text { Do you presume that costs of possible enforcement of contract } \\
\text { fulfilment by the contractors(s) would rather increase or decrease } \\
\text { in case of cooperation of several governments compared to the } \\
\text { variant when each government carries out this contract without } \\
\text { cooperation with other nations? }\end{array}$ \\
\hline \multicolumn{2}{|r|}{ OVERALL TRANSACTION COSTS (TRC) } \\
\hline $\begin{array}{l}\text { Overall armaments } \\
\text { project transaction costs } \\
(T R C)\end{array}$ & $\begin{array}{l}\text { Do you presume that transaction costs of a given armament project } \\
\text { would rather increase or decrease in the case of cooperation } \\
\text { of several governments compared to the variant when each govern- } \\
\text { ment carries out this contract without cooperation with other nations? }\end{array}$ \\
\hline
\end{tabular}

Source: Own. 
Transaction costs influence many activities both on the side of customer and contractor. In cases of internationally shared armaments projects, we can distinguish the so-called individual transaction costs (ITC) and collective transaction costs (CTC). ITC are traditional transaction costs, which occur even if a given contract is implemented by a given government without cooperating with other governments. Further classification of ITC has been described previously in this paper. CTC relate to searching for partners demanding a similar commodity, negotiating terms and conditions of mutual cooperation among partners forming a "weapon system club", and monitoring fulfilment of agreement among partners. Overall transaction costs (TRC) of an internationally shared project then represent the sum of ITC and CTC. If a given armaments contract is being carried out by a single government, TRC are represented by ITC. Based on Hobbs (1997) and Matthews (1986), both of these categories of transaction costs have been classified as information, monitoring and enforcement transaction costs. So defined transaction costs have been further analysed in relation to overall armaments project costs $(T O C)$ and in relation to key side benefits of international cooperation in armaments projects, i.e. the level of project transparency $(P T R)$.

\subsection{Hypotheses and Methods of their Verification}

In order to identify relations and dependencies among determinants, values of which have been gathered in relation to international armaments cooperation, six hypotheses have been formulated. These hypotheses are focused on key cost considerations of international armaments cooperation:

$H_{1}$ : Is there any relationship between project transparency $(P T R)$ and project total costs $(T O C)$ ?

$\mathrm{H}_{2}$ : Is there any relationship between the expected project total costs (TOC) decrease and the anticipated development of a given project's overall transaction costs (TRC)?

$H_{3}$ : Is there any relationship between project individual transaction costs (ITC) and project total costs $(T O C)$ ?

$H_{4}$ : Do collective (weapon system club) transaction costs (CTC) behave similarly to project total costs $(T O C)$ ?

$H_{5}$ : Do the empirically identified factors correspond with theoretical classification of transaction costs as individual and collective ones?

$H_{6}$ : Do the responds of individual segments of responders (Czech vs. international; industry vs. contracting authorities vs. academia) correlate?

These hypotheses have been verified using data resulting from statistical assessment of expectations declared by expert community. To identify decisive relations among determinants of international armaments cooperation, pairs of these determinants (variables) have been arranged. The measure of association of each of these examined pairs of variables has been characterized by Spearman's rank correlation coefficient $S R$. To compare the levels of subject-matter experts' expectations in replay to individual 
questions of the survey, Wilcoxon paired test has been applied, testing statistics $Z$ calculated and $p$-value determined. Furthermore, Man Whitney test has been used to examine the test statistics $M W$ and $p$-value were calculated for comparing of independent samples. Finally, Kruskal Wallis test $(K W$ statistics, $k$ degrees of freedom and $p$-value were calculated) has been applied for multiple comparisons of differences among the categories of experts. For detailed description of the above mentioned statistical methods, used to test hypothesis within this paper, see Agresti (2002).

To identify individual and collective transaction costs defined above in this paper, factor analysis has been applied (see Johnson and Wichern, 2007; Odehnal and Michálek, 2009). The number of factors has been determined based on a cumulative percentage of explained variability where the authors mentioned above recommend explaining at least $70 \%$ of the total variability. Furthermore, the rotated matrix of factor loadings (varimax rotation) has been used to identify the factors structure of transaction costs.

\subsection{Statistical Evaluation of Anticipated Relationships - Empirical Results}

To describe the results of the survey and verify relations among individual categories of costs, besides using their basic characteristics Spearman's rank correlation coefficients have been calculated in order to examine relation between the individual pairs of variables. The matrix of Spearman's rank correlation coefficients has been used as a basis for subsequent factor analysis. The Table 4 demonstrates (bold print indicates those correlation coefficients that are statistically significant at the $5 \%$ significance level) that the variable of expected project total costs (TOC) positively and statistically significantly correlates (at the $5 \%$ significance level) with the following variables:

- Overall transaction costs (TRC), $S R=0.45$,

- Project transparency $(P T R), S R=0.40$,

- Costs of negotiation terms and conditions with contractor(s) $(C N C) S R=0.40$.

Table 4

The Matrix of Spearman's Rank Correlation Coefficients

\begin{tabular}{|c|c|c|c|c|c|c|c|c|c|c|}
\hline Variable & TOC & $I C C$ & $T R C$ & $C N C$ & CMC & CEC & $P S C$ & $P N C$ & PEC & PTR \\
\hline TOC & 1.00 & 0.11 & 0.45 & 0.40 & 0.07 & 0.07 & 0.15 & 0.10 & 0.16 & 0.40 \\
\hline$I C C$ & 0.11 & 1.00 & 0.61 & 0.26 & 0.13 & 0.15 & 0.30 & 0.06 & -0.22 & -0.20 \\
\hline$T R C$ & 0.45 & 0.61 & 1.00 & 0.27 & 0.33 & 0.10 & 0.46 & 0.27 & 0.05 & -0.04 \\
\hline CNC & 0.40 & 0.26 & 0.27 & 1.00 & 0.34 & 0.41 & 0.02 & 0.05 & 0.15 & -0.04 \\
\hline CMC & 0.07 & 0.13 & 0.33 & 0.34 & 1.00 & 0.73 & -0.13 & -0.36 & 0.15 & -0.09 \\
\hline CEC & 0.07 & 0.15 & 0.10 & 0.41 & 0.73 & 1.00 & -0.28 & -0.41 & 0.36 & -0.28 \\
\hline$P S C$ & 0.15 & 0.30 & 0.46 & 0.02 & -0.13 & -0.28 & 1.00 & 0.58 & 0.07 & -0.18 \\
\hline$P N C$ & 0.10 & 0.06 & 0.27 & 0.05 & -0.36 & -0.41 & 0.58 & 1.00 & 0.31 & 0.03 \\
\hline PEC & 0.16 & -0.22 & 0.05 & 0.15 & 0.15 & 0.36 & 0.07 & 0.31 & 1.00 & -0.05 \\
\hline PTR & 0.40 & -0.20 & -0.04 & -0.04 & -0.09 & -0.28 & -0.18 & 0.03 & -0.05 & 1.00 \\
\hline
\end{tabular}

Source: Own calculation. 
In addition, the variable of costs of possible enforcement of contract fulfilment by the contractor(s) (CEC) statistically significantly correlates with contract negotiation cost $(C N C) S R=0.41$ as well as monitoring cost $(C M C), S R=0.73$. The variable of costs of negotiating joint project terms and conditions with partner(s) $(P N C)$ significantly at the $5 \%$ significance level and positively correlates with costs of searching for partner(s) ( $P S C$ ), $S R=0.58$ and significantly negatively correlates with the variable of costs of possible enforcement of contract fulfilment by the contractor(s) (CEC), $S R=-0.41$. Finally, the last significant correlation has been identified between the variable of project's overall transaction costs $(T R C)$ and costs of searching for partner(s), $(P S C), S R=0.46$.

When performing further analyses and interpretations of the results gathered within the survey, attention has been focused on verifying hypotheses $H_{1}-H_{6}$ formulated in the Section 3.2 of this paper.

\section{Relationship between PTR and TOC $-\mathrm{H}_{1}$}

Essential characteristics of these variables are as follows: Mean $P T R=1.74$, Median $P T R=1.00$, Mean $T O C=3.63$, Median $T O C=4.00$ and $S R=0.40, p$-value $<0.05$. So, we can conclude that project total costs $(T O C)$ statistically significantly and positively correlate with project transparency $(P T R)$ at the $5 \%$ significance level. First, let us focus on the total costs of a given project (TOC). Generally, TOC are expected to at least moderately decrease in the case of internationally shared projects (expectation of $77.7 \%$ of responders, just $22.3 \%$ of them has expected $T O C$ increase).

Further parts of the survey examined bases for this expectation, i.e. what are the causes of the expectation of an at least moderate decrease in total costs of an internationally shared project?

The survey results have further indicated the expected increase in armaments project transparency $(P T R)$ in the case of its international sharing. In the case of international sharing of an armaments project, $51.1 \%$ of the responders have expected a substantial increase in its $P T R, 33.3 \%$ responders have anticipated a moderate PTR improvement. An unchanged $P T R$ level has been expected by $7.4 \%$ of responders. The same number of responders, i.e. $7.4 \%$ has anticipated moderate or significant $P T R$ deterioration. It means that the most frequent expectation has accented substantial PTR improvement, which can be viewed - besides assumed economic benefits - as one of the noneconomic benefits of international sharing of armaments contracts.

Is there any relation between PTR and project total costs (TOC)? As the survey results show, there is a significant difference in the level of expectations (Wilcoxon $Z=3.944993$; $p$-value $=0.000080$ ). This expectation results from international mechanism within given "weapon system club" guaranteeing monitoring of behaviour of not just contractor(s) but also national governments and other agencies involved. So, enhanced PTR can be viewed as one of the important drivers of cost decrease in international armaments projects. The relationship described is illustrated in detail in 
the Figure 1 below. The anticipation of decreased TOC of an internationally shared armaments project has been confirmed (moderate decrease represents the most frequent reply; Median $T O C=$ Mode $T O C=$ moderate decrease).

Figure 1

Histogram of Multiple Variables TOC and PTR

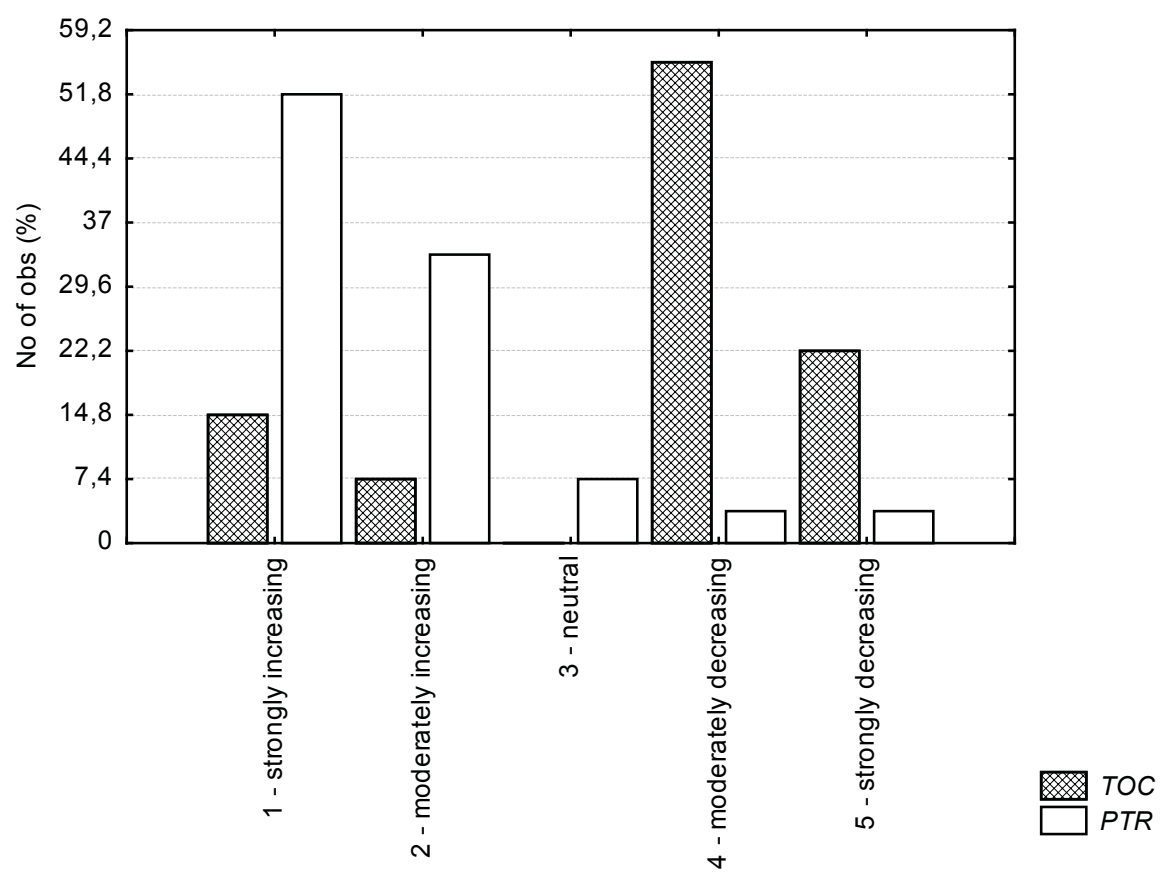

Source: Own calculation.

\section{Relationship between TOC and TRC $-\mathrm{H}_{2}$}

Is there any relationship between the expected TOC decrease and the anticipated development of a given project's overall transaction costs $(T R C)$ ? Basic characteristics of these variables are as follows: Mean $T O C=3.63$, Median $T O C=4.00$, Mean $T R C=3.11$, Median $T R C=3.00$ and $S R=0.45, p$-value $<0.05$. This implies that project total costs $(T O C)$ statistically significantly and positively correlate with project's overall transaction costs $(T R C)$ at the $5 \%$ significance level. The Wilcoxon test has confirmed a significance of the difference between the expected level of TOC and $T R C$ are only at $p$-value $<0.1(Z=1.866633 ; p$-value $=0.061954)$. It means that generally, there is low significance in the difference in the levels of expectations when comparing TRC and TOC. So, we can conclude that in spite of growing complexity of shared project management, resulting from a higher number of partners pooled within given weapon systems club, transaction costs do not grow as expected and therefore do not hinder the expected decrease in total costs of a given project. 


\section{Relationship between ITC and TOC $-\mathrm{H}_{3}$}

Similarly, when assessing the difference in anticipated levels of the TOC and TRC variables, the Wilcoxon test has been also used to assess the differences in expected levels of pairs of variables representing individual transaction costs (ITC) in relation to project total costs (TOC). Survey results regarding individual components of ITC (ICC, CNC, CMC and CEC) variables are demonstrated by the Figure 2 below.

Spearman's rank correlation coefficients between the variables TOC and individual components of ITC are as follows: ICC - TOC ( $S R=0.11$; $p$-value $>0.05), C N C-$ TOC $(S R=0.40 ; p$-value $<0.05), C M C-$ TOC $(S R=0.07 ; p$-value $>0.05), C E C-$ TOC $(S R=0.07 ; p$-value $>0.05)$. At the $5 \%$ significance level statistically significant and positive correlation has been identified only for the relationship between $T O C$ and $C N C$.

The results of comparisons of ITC with TOC, i.e. results of comparisons of pairs of variables in question are as follows: ICC - TOC $(Z=0.442664$; $p$-value $=0.658009)$, CNC - TOC $(Z=0.544379 ; p$-value $=0.586181), C M C-$ TOC $(Z=1.112245$; $p$-value $=0.266034), C E C-$ TOC $(Z=1.277428 ; p$-value $=0.201452)$. Based on these results, it is evident that no statistically significant difference at the $5 \%$ significance level has been detected for the levels of expectations of the components of ITC and TOC variables.

Figure 2

Histogram of Multiple Variables ICC, CNC, CMC and CEC

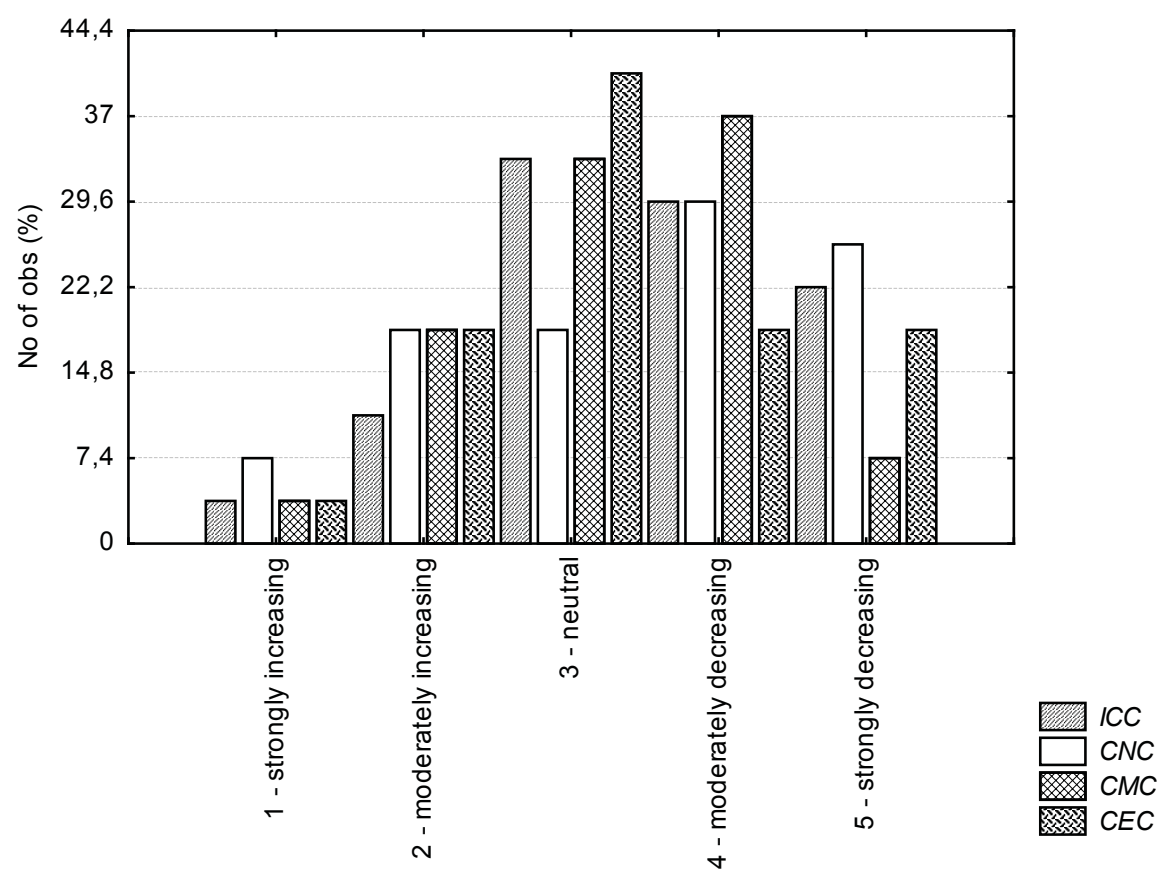

Source: Own calculation. 
The survey results show that components of ITC are expected to either moderately decrease $(I C C, C N C)$ or remain unchanged $(C M C, C E C)$ in the case of cooperation of several governments compared to the variant when each government carries out a given project independently. So, ITC are expected to have a decreasing tendency with approaching international sharing of a given armaments project, and therefore contribute to the expected decrease in project total costs $(T O C)$.

\section{Relationship between CTC and TOC $-\mathrm{H}_{4}$}

Do collective transaction costs $(C T C)$ behave similarly to $T O C$ ? To find an answer to this question, expectations included in the survey in relation to $P S C, P N C$ and $P E C$ variables have been visualized (see the Figure 3 below). In applying analogous methods as in the case of ITC components, the difference in the levels of expectations has been assessed: PSC - TOC $(Z=1.505099$; $p$-value $=0.132300), P N C-$ TOC $(Z=0.594651 ; p$-value $=0.552077)$, PEC - TOC $(Z=3.936686 ; p$-value $=0.00008)$. These results show that a statistically significant difference at the $5 \%$ significance level has been detected only for expectations of the PEC and TOC variables.

Figure 3

Histogram of Multiple Variables PSC, PNC and PEC

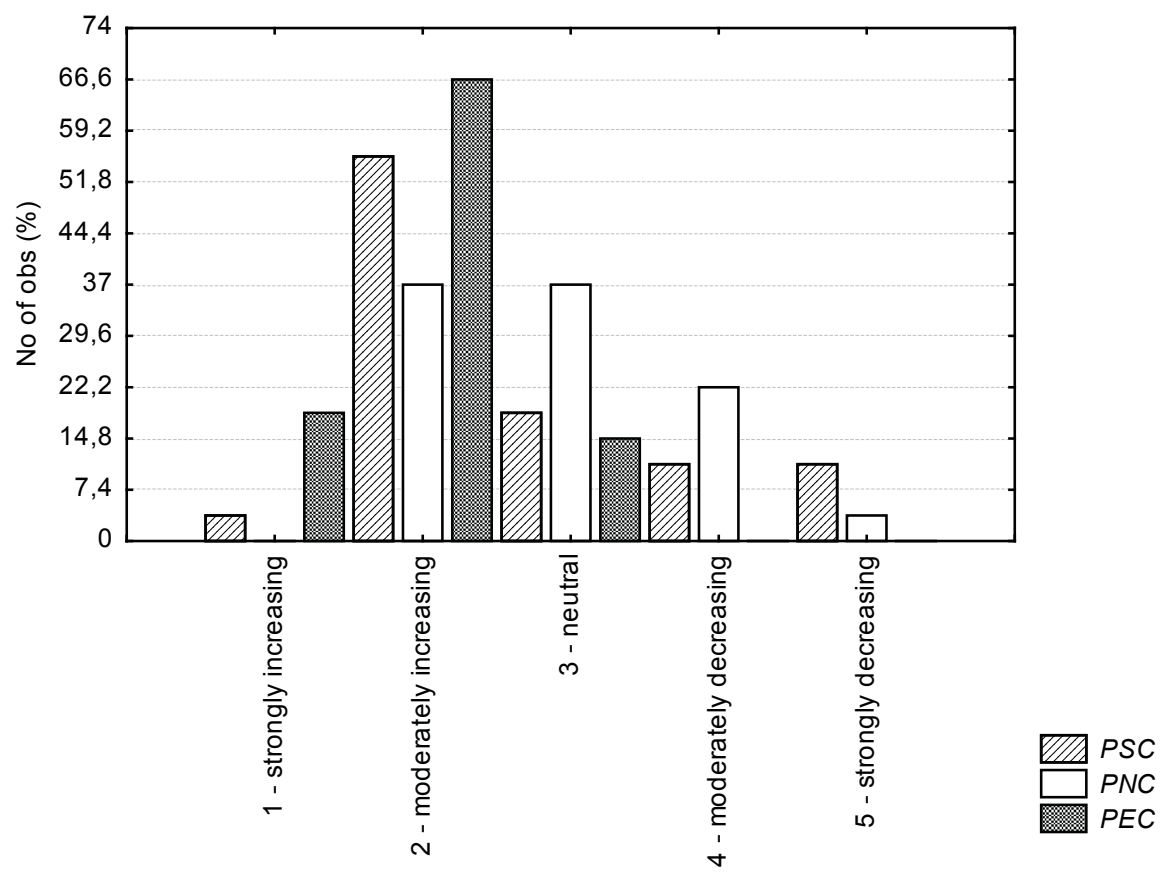

Source: Own calculation. 
Spearman's rank correlation coefficients are as follows: PSC - TOC $(S R=0.15$; $p$-value > 0.05), PNC - TOC $(S R=0.10 ; p$-value $>0.05), P E C-T O C ~(S R=0.16$; $p$-value $>0.05)$. At the $5 \%$ level of significance, all correlations have proved to be statistically insignificant.

Based on the three latter dependencies described above, we can conclude that CTC will moderately increase in case of international sharing of a given armaments project.

Do the empirically identified factors correspond with theoretical classification of transaction costs as individual and collective ones? $-\mathrm{H}_{5}$

In order to identify individual and collective transaction costs defined above in this paper, factor analysis has been applied. Based on the set of the ten determinants, five variables have been selected (costs of negotiation terms and conditions with contractor(s) (CNC), costs of monitoring of contract fulfilment by the contractor(s) $(C M C)$, costs of possible enforcement of contract fulfilment by the contractor(s) $(C E C)$, costs of searching for partner(s) (PSC) and costs of negotiating joint project terms and conditions with partner(s) $(P N C)$ ), characterizing potential transaction costs, generated both at individual and collective approach to arms procurement. Using the correlation matrix of the selected five variables, a factor loadings matrix has been determined and subsequently rotated by the varimax method. After performing this rotation, results have shown that the first two factors have explained nearly $75 \%$ of the total variability, which regarding conclusions of other authors (Johnson and Wichern, 2007; Odehnal and Michálek, 2009) can be viewed as statistically sufficient. Table 5 shows the rotated factor loadings matrix, which demonstrates that the first factor is saturated by variables $C N C, C M C, C E C$ and explains about $40 \%$ of variability. The second factor is saturated by variables $P S C$ and $P N C$ and explains about $35 \%$ of variability. As already mentioned above, by applying factor analysis of data gathered within the survey, two factors of transaction costs have been identified. Regarding the resulting factor loadings, they have been identified as:

a) Factor F1: Individual Transaction Costs (ITC) - low F1 values illustrate decreased costs described by $C N C, C M C$ and $C E C$ variables.

b) Factor F2: Collective Transaction Costs (CTC) - high F2 values correspond with increased $P S C$ and $P N C$ variables.

Both of the empirically identified factors confirm theoretical assumptions, described above in this paper.

Do the expectations declared by individual segments of responders answer the key questions similarly? $-H_{6}$

The expected dependencies collected and analysed within this survey represent the expectations of three categories of experts, namely of $19 \%$ of defense industry experts, $18 \%$ of contracting authorities' staff and $63 \%$ of experts from universities and research institutes. Consistency of expectations of these three categories of 
experts has been examined using the Kruskal Wallis Test for multiple comparisons (e.g. $K W=7.386543, k=3$, $p$-value $=0.0605$ for $T O C ; K W=2.638248, k=3$, $p$-value $=0.4508$ for $T R C ; K W=3.966463, k=3, p$-value $=0.2651$ for $P T R)$. In all examined cases, differences among the categories of experts have been shown to be unimportant at the $5 \%$ significance level. Therefore, it is possible to state that responders representing all of the three categories have declared identical anticipations, which confirms the validity of the survey results.

Table 5

Factor Loadings Matrix

\begin{tabular}{|l|r|r|}
\hline Variable & \multicolumn{1}{|c|}{ Factor $\mathbf{1}$} & \multicolumn{1}{c|}{ Factor $\mathbf{2}$} \\
\hline CNC & $\mathbf{- 0 . 7 5 4 0 1 3}$ & 0.259073 \\
\hline CMC & $\mathbf{- 0 . 8 2 3 6 1 3}$ & -0.257654 \\
\hline CEC & $-\mathbf{0 . 8 3 1 7 6 5}$ & -0.361023 \\
\hline PSC & 0.011936 & $\mathbf{0 . 8 5 3 1 1 2}$ \\
\hline PNC & 0.184195 & $\mathbf{0 . 8 7 2 8 4 4}$ \\
\hline Explained Variability (\%) & 39.4555 & 35.0700 \\
\hline Cumulative Explained Variability (\%) & 39.4555 & 74.5255 \\
\hline
\end{tabular}

Source: Own calculation.

Although international community has been addressed dominantly within the survey, approx. $55.6 \%$ of the active responders represented the Czech expert community, while the other $44.4 \%$ included experts from other NATO and/or EU member countries. So, the results of this survey have been strongly influenced by the "Czech point of view".

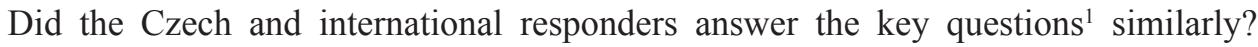
In fact, using the Mann-Whitney test this time, there was no significant difference found between the dependencies anticipated by the Czech and international experts (e.g. $M W=0.439155, p$-value $=0.66055$ for $T O C ; M W=0.268373$, $p$-value $=0.78841$ for TRC; $M W=-0.756323$, $p$-value $=0.44946$ for $P T R)$.

\section{Conclusion}

Based on a survey of expectations of international community, a moderate decrease in overall costs borne by individual governments is to be anticipated in case of an internationally shared armaments project. Mutual control among the weapon system club partners can be viewed as one of the greatest benefits of international armaments cooperation, resulting in higher project transparency and therefore, lower costs. Transaction costs are expected to remain unchanged after approaching international armaments cooperation. However, their individual component is to decrease, mainly

1 The key questions have related to the variables of total costs (TOC), overall transaction costs (TRC) and project transparency (PTR). 
due to the expected decrease of costs of collecting information on requirements and costs of negotiating terms and conditions of contract with contractor(s). On the other hand, collective component are to increase proportionally. This results mainly from the increase of costs related to negotiating terms and conditions of cooperation with given weapon system club partner(s) and costs of monitoring and enforcing compliance by partner(s). Nevertheless, in the case of repeating cooperation among nations pooled in a given weapons system club for several projects, a moderate decrease in collective transaction costs can be further expected. In relation to transaction costs, two factors have been identified, explaining app. $75 \%$ of the total variability. These two factors correspond with the definition of individual and collective transaction costs defined in this paper. Validity of the survey results has been verified by proving consistency of replies of individual groups of responders.

\section{References}

Agresti, A. (2002), Categorical Data Analysis, John Wiley \& Sons.

Audit Commission. (1995), "Making Markets: A Review of the Audits of the Client Role for Contracted Services". Bulletin, March, London, HMSO.

Coase, R. H. (1937), "The Nature of the Firm". Economica, New Series, Vol. 16. Reprinted in: Stigler, Boulding, Readings in Price Theory, Homewood, pp. 331-541.

Dušek, L., Ortman, A., Lizal, L. (2005), “Understanding Corruption and Corruptibility through Experiments." Prague Economic Papers, Vol. 14, No. 2, pp. 147-162.

Dyer, J. (1997), "Effective Interfirm Collaboration: How Firms Minimize Transaction Costs and Maximize Transaction Value", Strategic Management Journal, Vol. 18, No. 7, pp. 535-556.

Euroactiv. (2006), European Union Defence Equipment Policy. (Retrieved March 23, 2012, from http:// www.euractiv.com/en/security/eu-defence-equipment-policy/article-117487.)

European Commission. (2003), A Secure Europe in a Better World - European Security Strategy, 2003. Brussels: European Commission, 2003. 15 p. (Retrieved February 3, 2012, from http://www. consilium.europa.eu/uedocs/cmsUpload/78367.pdf.)

Furubotn, E. G., Richter, R. (1998), Institutions and Economic Theory, The Contribution of the New Institutional Economics, Ann Arbor: The University of Michigan Press. 1998.

Gareth, R., Hill, W. L. (1988), "Transaction Cost Analysis of Strategy-Structure Choice”. Strategic Management Journal, Vol. 9, No. 2, pp. 159-172.

Hartley, K. (1995), "Industrial Policies in the Defense Sector." In Hartley, K., Sandler, T. Handbook of Defense Economics. Volume 1. Amsterdam: Elsevier, p. 478.

Hobbs, J. E. (1997), "Measuring the Importance in Cattle Marketing". American Journal of Agricultural Economics. Vol. 79, No. 4, pp.1083-1095.

Johnson, R. A., Wichern, D. W. (2007), Applied Multivariate Statistical Analysis. Pearson Prentice Hall.

Kerlinger, F. N. (1986), Foundations of Behavioral Research. Rinehart and Winston.

Krč, M., Kamiňski, T. (1996), Ekonomika obrany - obranné hospodářství. Brno: Vojenská akademie $v$ Brně.

Matthews, R. C. O. (1986), "The Economics of Institutions and the Sources of Growth". Economic Journal, Vol. 96, No. 384, pp. 903-918.

NATO. (2012), Summit Declaration on Defence Capabilities: Toward NATO Forces 2020. Chicago: NATO, 2012. (Retrieved February 4, 2012, from http://www.nato.int/cps/en/natolive/official_ texts_87594.htm?mode=pressrelease.) 
North, D.C., Wallis, J.J. (1970), "Measuring the Transaction Sector in the American Economy 18701970". Long - Term Factors in American Economic Growth. The Income and Wealth Series. Vol. 51. Chicago University Press.

Odehnal, J., Michálek, J. (2009), "Hodnocení konkurenceschopnosti vybraných regionů Evropské unie”. Ekonomický časopis. Vol. 57, No. 2, pp. 113-131.

Otáhal, M. (2007), "Why Is Corruption a Problem of the State?" Prague Economic Papers, Vol. 2007, No. 2. pp. 65-79.

Pavel, J. (2004), “Vliv transakčních nákladu na zabezpečování veřejných služeb”. In Mech, J. (ed.) Konkurence ve veřejném sektoru. Brno.

SIPRI. (2012), Background Paper on SIPRI Military Expenditure Data, 2011. Stockholm: SIPRI, 2012. 10 p. (Retrieved January 24, 2012, from http://www.sipri.org/research/armaments/milex.)

Stiglitz, J. E. (1997), Ekonomie veřejného sektoru. Praha: Grada Publishing.

Vahabi, M. (2011), “Appropriation, Violent Enforcement, and Transaction Costs: a Critical Survey." Public Choice, No. 1-2, 2011, pp. 227-253.

Walsh, K., Davis, H. (1993), Competition and Services: The Impact of the Local Government Act 1988, Department of the Environment, University of Birmingham, HMSO, United Kingdom.

Weber, K. (1997), "Hierarchy amidst Anarchy: A Transaction Costs Approach to International Security Cooperation." International Studies Quarterly, Vol. 41, No. 2, pp. 321-340.

Williamson, O. E. (1985), "The Economic Institutions of Capitalism". The Free Press, New York.

Williamson, O. E. (1986), Economic Organization: Firms, Markets and Policy Control. Hertfordshire, UK: Harvester Wheatsheaf. 